\title{
YIM-P59. Relationships between the Th17 and innate lymphoid cell signature in enthesitis related arthritis
}

\author{
Hannah Lom ${ }^{1,2^{*}}$, Kiran Nistala ${ }^{3}$, David Bending ${ }^{1}$, Yiannis loannou ${ }^{2,4}$, Mona Bajaj-Elliott ${ }^{1}$, Lucy Wedderburn ${ }^{1,2}$ \\ From 21st European Pediatric Rheumatology (PReS) Congress \\ Belgrade, Serbia. 17-21 September 2014
}

\section{Introduction}

Enthesitis related arthritis (ERA), a subtype of juvenile idiopathic arthritis (JIA) has a close association with HLAB27. Previous studies suggest a role for Th17 cells in disease pathogenesis; at present the link between Th17 immunity and HLA-B27 is unknown. Innate lymphoid cells (ILCs) form a bridge between the innate and adaptive immune systems, producing signature cytokines in response to cytokine stimulation. ILCs lack common surface markers associated with known leukocyte lineages, but constitutively express the IL-7 receptor- $\alpha$ (CD127). ILCs can be divided into 3 types $(1,2$ and 3$)$ which mimic the T cell subsets (Th1, Th2 and Th17) based on their transcription factor and cytokine profiles.

\section{Objectives}

To investigate Th17 and ILC populations in the joint and blood of ERA JIA patients.

\section{Methods}

Th17 cells and ILCs from the peripheral blood mononuclear cells (PBMC) of healthy controls and ERA patients and synovial fluid mononuclear cells (SFMC) of ERA patients were analysed by flow cytometry $(n=7)$. Th17 cells were identified as $\mathrm{CD} 3$ positive $\mathrm{CD} 4$ positive $\mathrm{T}$ cells which secreted interleukin (IL)-17 after stimulation with PMA and ionomycin. ILCs were identified as lineage (CD3, $\alpha \beta$ TCR, $\gamma \delta$ TCR, CD19, CD14, CD11c, CD16, CD1a, CD34, CD94, BDCA2 and FceRI $\alpha$ ) negative, CD45 positive, CD127 positive cells.

\section{Results}

Th17 cells $(\mathrm{CD} 3+\mathrm{CD} 4+\mathrm{IL}-17+)$ were enriched in the joint compared to the blood of ERA patients and healthy blood $(\mathrm{p}=0.0446)$. Within the Th17 populations, an increase of IL-17/IFN $\gamma$ double-producing cells was found in the joint compared to the blood of ERA patients. Compared to available data in other types of JIA, the number of Th17 cells was higher in ERA (median = $4.1 \%$ ) than other JIA subtypes, including extended oligoarthritis (median $=1.99 \%)$. An enrichment of ILCs was observed in the joint of ERA patients (0.15-0.5\% of lymphocytes) compared to healthy blood $(<0.1 \%)(\mathrm{p}=0.0114)$. Interestingly, a positive correlation between Th17 and ILC numbers in the joint of ERA patients was demonstrated $(\mathrm{r}=0.6)$.

\section{Conclusion}

These data show that Th17 cells and ILCs are enriched in the joints of ERA JIA patients. Further work is warranted to explore the interplay between these two immune cell populations in the context of ERA.

\section{Disclosure of interest}

None declared.

\section{Authors' details}

IInfection, Inflammation and Rheumatology Section, UCL Institute of Child Health, London, UK. ${ }^{2}$ Arthritis Research UK Centre for Adolescent Rheumatology, London, UK. ${ }^{3}$ Centre for Rheumatology, University College London, London, UK. ${ }^{4}$ Adolescent and Adult Rheumatology, Great Ormond St Hospital \& University College London Hospitals NHS Foundation Trusts, London, UK.

Infection, Inflammation and Rheumatology Section, UCL Institute of Child

Health, London, UK

Full list of author information is available at the end of the article 

and innate lymphoid cell signature in enthesitis related arthritis. Pediatric Rheumatology 2014 12(Suppl 1):Y6.

Submit your next manuscript to BioMed Central and take full advantage of:

- Convenient online submission

- Thorough peer review

- No space constraints or color figure charges

- Immediate publication on acceptance

- Inclusion in PubMed, CAS, Scopus and Google Scholar

- Research which is freely available for redistribution

Submit your manuscript at www.biomedcentral.com/submit
C Biomed Central 